Original Research Paper

\title{
Factors Influencing Livestock Investment Decisions in West Sumatra: A Social Capital in Business Scheme Known as Seduaan
}

\author{
${ }^{1}$ Fitrimawati and ${ }^{2}$ Jafrinur \\ ${ }^{1}$ Faculty of Animal Science, Andalas University, Padang, Indonesia \\ ${ }^{2}$ Faculty of Agriculture, Andalas University, Padang, Indonesia
}

\author{
Article history \\ Received: 28-03-2020 \\ Revised: 25-04-2020 \\ Accepted: 19-05-2020 \\ Corresponding Author: \\ Fitrimawati \\ Faculty of Animal Science, \\ Andalas University, Padang, \\ Indonesia \\ Email: fitrimawati@ansci.unand.ac.id
}

\begin{abstract}
This study aimed to analyze the effect of social capital on investment decision making in the business of smallholder cattle breeding with the same system. The data of this research were gathered through surveys and interviews with farmers and investors in Cow business in the province of West Sumatra. Data collected is in the form of latent constructs analyzed through the Structural Equation Modeling using Partial Least Square (SEM-PLS). The results of the study showed that the Minangkabau people's investment decisions in the business of cattle through the social capital traditional scheme known as seduaan are influenced by social capital, risk and religion while the return did not affect investment decisions.
\end{abstract}

Keywords: Livestock Business, Investment Decisions, Social Capital, Minangkabau Ethnic, Seduaan System

\section{Introduction}

The government's target in achieving beef selfsufficiency is $90 \%$ of national consumption needs that must be supplied from domestic production. However, the problem is that almost all local meat supplies come from small-scale people's farms where cattle are raised by two to three (Yulia et al., 2017). Maintenance of cattle in Indonesia has not been oriented to large-scale businesses but is still a side business. This condition is almost applicable in all regions in Indonesia. In West Sumatra, livestock business is still classified as a side business of agricultural business. Besides rice cultivation Minangkabau farmers in also practice gardening, raising fish and livestock. This mix of farming patterns prevents cattle populations from meeting domestic needs. Therefore, many programs are carried out by the government to further motivate farmers to develop their livestock business intensively. These programs are funded by the Regional Revenue and Expenditures Budget or Anggaran Pendapatan dan Belanja Daerah (APBD), State Budget or Anggaran Pendapatan dan Belanja Negara (APBN) and Credit Programs by Banks. The funds channeled through these programs have reached trillion Rupiah.

The people of West Sumatra have contributed to alleviating the burden on the government budget in animal husbandry development (Indrayani, 2012) (Basyar, 2018), especially through cattle farming with an old system referred to as seduaan. This ancient system rooted in the Minangkabau tradition compels community and family members to come together and help one another. When viewed from the perspective of agribusiness, raising cattle requires large financial capital to purchase seeds. But the Minangkabau people have been able to since they built livestock agribusiness. This can all apply, one of which is based on the social capital they have in maintaining cows with an old system. For the Minangkabau people who have considerable financial strength, they will share it with their relatives who cannot afford one. The trick is to invest in cattle raising business, but the maintenance is carried out by those who cannot afford it. If the cow gives birth, the calves will be shared between two individuals. As a result, it prevents many low-income individuals from having their own cows. So great is the social capital possessed by the Minangkabau ethnic group in improving their welfare, the standard of living and the future of their relatives. This social capital has unwittingly actually built up cattle farming in West Sumatra, which is why West Sumatra has no shortage of cattle supply critically to fulfill the need for nutrition derived from beef and the need for cattle for sacrifice on Eid al-Fitr. 
This culture developed because of the Minangkabau ethnicity in their daily lives practicing the principle of high solidarity and cooperation (Henri, 2013). This is recommended by the Minangkabau tradition. This social capital has been embedded within the Minangkabau society (Naim, 1984 Darwis, 2004; Fitrimawati, 2013).

Based on the facts and phenomena that occur in the business of people's cattle breeding through the seduaan system in West Sumatra, it is suspected that there is an influence of social capital in the Minangkabau ethnic investment decisions. Rarely is the result of research on the role of social capital in making individual investment decisions. Research on investment decisions is a new issue so the majority of research on individual investment decisions encountered is only focused on investment decisions in the stock market. Research on investment decisions has been carried out by several researchers. According to Kadariya (2012) and Sarwar and Afaf (2016), individual investment decisions are influenced by economic and psychological factors. Economic factors consist of information about company performance, especially financial performance, annual reports for shareholders, market performance of the company's products, shareholder value, information on price movements. This means that changes or price fluctuations because of differences in demand and supply in a trade. Suman and Warne (2012) explain that price fluctuations affect individual investment patterns. When investors invest their money, the main goal is to benefit from it. When people invest their money in something, the main goal is to benefit from it. They do not hesitate to invest in risky securities because they think that high risk can give them high returns (Suman and Warne, 2012). Islamoğlu et al. (2015) examined the relationship between community religions to investor investment decisions in the City of Bartin. Based on the results of previous studies, social capital has not been found as a determining factor in making individual investment decisions. Therefore, this study aims to analyze the role of social capital in making investment decisions in the business of cows.

\section{Methods}

Exploratory approach was used in this research to gain a deeper understanding of the factors influencing the Minangkabau people's investment decisions in cattle business through a social capital system referred to as the seduaan system. This exploratory study was conducted through interviews and surveys with several key informants in the agricultural business. These two procedures were intended for triangulation purpose. The research was conducted in West Sumatra home to the Minangkabau ethnic group. The research location was determined purposively. The Minangkabau ethnic group was chosen as research subject due to it long existing agricultural business practice known to the Minangkabau people as seduaan, a social capital originating from religious and cultural norms and values intended for improving the welfare of community members. The data analysis technique used in this study is the Structural Equation Modeling method with Partial Least Square (SEM-PLS). SEM is a combination of two separate statistical methods, namely factor analysis and simultaneous equation modeling developed in econometrics. SEM can analyze latent variables that cannot be observed directly (unobservable) but can be measured through measurable indicators (Kusnendi, 2008; Hair, 2006). Two models need to be formulated in the use of SEM-PLS applications namely outer and inner models. The outer model indicates the relationship between the variable and the manifest. It was used for measurement (measurement model). The inner model, on the other hand, specifies the relationship between latent variables. It is also referred to as a structural model.

Outer model analysis aimed to explore the validity of each indicator and test the reliability of the construct. Indicator validity criteria were measured by convergent validity, while construct reliability was measured by composite reliability and Average Variance Extracted (AVE). The convergent validity of the measurement model gets a value greater than 0.7. However, for the initial research of the development of a scale of measurement the loading values of 0.5 to 0.6 were considered sufficient (Chin, 1998). The discriminant validity of the measurement model was assessed by comparing the value of the square root of the Average Variance Extracted (AVE) of each construct with the other constructs in the model. If the AVE square root value of each construct is greater than the correlation value between one construct and other constructs within the model, it is said to have good discriminant validity values. The recommended AVE value must be greater than 0.50 . Composite reliability indicator blocks that measure a construct can be evaluated in two types: Internal consistency with the rule of thumb which is 0.70. and Cronbach Alpha which is greater than 0.7. The structural model or inner model is evaluated using R-square for the dependent construct, the T-test and the significant coefficient of structural path parameters. Changes in the value of R-square can be used to assess the influence of certain independent latent variables on dependent latent variables whether they have substantive effects. The structural model of this research is formulated in the form of structural equation as in Fig. 1:

$$
\begin{aligned}
& \text { Investment decision }=\beta_{1} \text { Social Modal } \\
& +\beta_{2} \text { Return }+\beta_{3} \text { Risk }+\beta_{4} \text { Religion }+\xi_{1}
\end{aligned}
$$




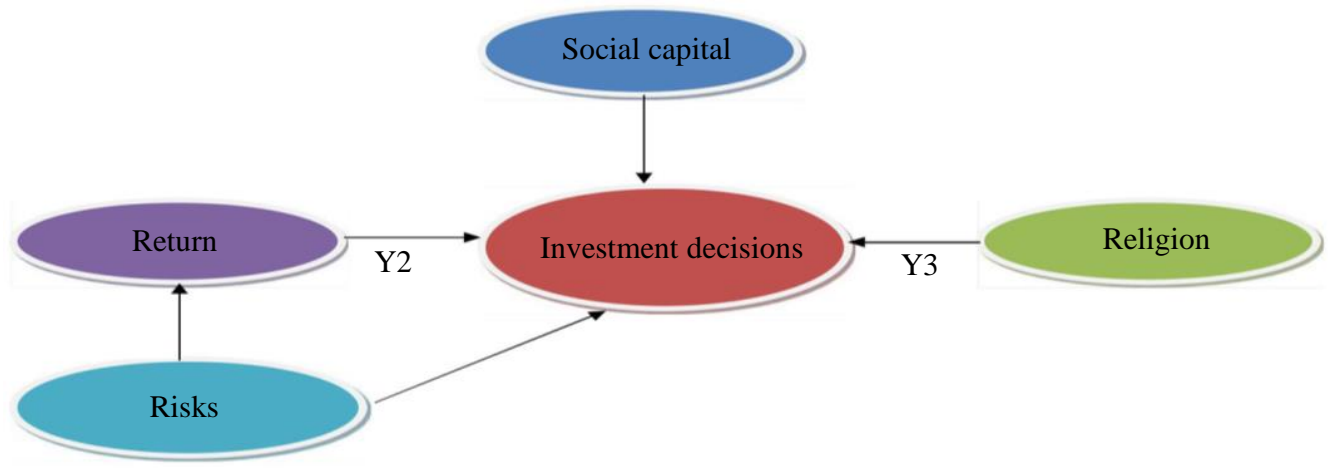

Fig. 1: Structural model

\section{Results and Discussion}

In this study, an investment decision model was built in a beef cattle breeding business with an old system. The results of data analysis using SEM-PLS were obtained through two stages, namely the results of the outer model and the results of the inner model. The results of the outer model are convergent results of validity, discriminant and composite reliability and Cronbach Alpha. The results of the outer model are shown in Table 1. The results of outer loading from this study were used to assess the validity of indicators for each variable. The value of cross-loading indicators that were less than 0.7 were excluded from the model. In this study, the value of the cross-loading used was greater than $0.70(0.835-0.963)$ so that the value of discriminant validity illustrated from the value of Average Variance Extracted (AVE) obtained was greater than 0.50 (Table 1). This means that the indicators used in this study are valid because $50 \%$ or more of the variance of the indicators can be explained.

The Composite Reliability value obtained for all constructs in this study ranges from 0.727-0.907 (Table 1 This shows that the construct indicators built on this model are reliable because this value is greater than the Rule of thumb, which is 0.70 . The indicator reliability test can also be done on the value of Cronbach Alpha. The Cronbach Alpha value obtained was greater than 0.7. (Table 1). This means that all construct indicators built in the model of investment decisions on the business of people's cows through the seducing system are reliable. It can be said that the instruments used in processing this research data are accurate, consistent and precise in measuring constructs.

The next step was to explain the results of the inner model of the SEM-PLS. The first analysis of the inner model was done with the value of R-Square. The RSquare value obtained is 0.658 . This value showed the strength of endogenous latent variables as predictions of the structural model where the investment variability of Decision Construction as an endogenous latent construct can be explained by the latent construct of Social Capital, Return, Risk and Religious at $65.8 \%$ while
$34.2 \%$ is another construct not explained in this model. This R-Square value is categorized as moderate.

The results of the next inner model will be used to analyze the influence of the constructs of Social Capital, Return, Risk and Religion on the Investment Decision construct of business investment in people's livestock through the old system. The effect of exogenous latent constructs on endogenous latent constructs is indicated by the statistical T-value. There are three of the exogenous latent constructs that have a statistical $\mathrm{T}$ value greater than 1.96, namely the construction of Social Capital, Return and Risk. This value indicates that Social, Risk and Religious Capital significantly influence ( $\mathrm{P}$-value $<\alpha 0.01$ and 0.05 ) investment Decisions. Social Capital has a significant positive effect and relationship ( $\mathrm{T}$ statistic $=4.334>1.96$ ) on the construct of Investment Decision (Table 2) This means that Minangkabau people's investment decisions in the farming with the seduaan system are strongly influenced by social capital and the higher the level of Minangkabau ethnic social capital, the more investment decisions in cattle. The dimensions of social capital practiced by Minangkabau ethnicity in influencing investment decisions are reciprocity and participation.

The Minangkabau ethnic group investing in the cattle business through seduaan is driven by their desire to be rewarded later. This proved they were expecting a return of good as much as 50\%. Additionally, their investment decisions are also driven by the desire to help relatives to live a better live. These two dynamics of social capital have significant influence over the Minangkabau people's cattle business investment plans. Aspects such as religion, cooperation, solidarity, togetherness and social responsibility do not significantly impact their investment decisions. These results are different from those found by Fitrimawati (2015) in her dissertation which concluded that these agricultural investment plans in West Sumatra are influenced by culture of social responsibility, cooperation, togetherness and trust. This difference is caused by the development of entrepreneurship; the majority of Minangkabau farmers invest money only in livestock business. That is why besides chipping in for social purposes, they also want to make money. 
Table 1: Validity value and reliability of outer models

\begin{tabular}{llll}
\hline Construct & Composite reliability & AVE & Cronbach alpha \\
\hline Investment decision & 0.840 & 0.724 & 0.724 \\
Social capital & 0.727 & 0.513 & 0.776 \\
Return & 0.764 & 0.507 & 0.731 \\
Risk & 0.867 & 0.766 & 0.745 \\
Religion & 0.907 & 0.830 & 0.863 \\
\hline
\end{tabular}

Table 2: Value of inner model

\begin{tabular}{llll}
\hline Constructive correlation & Original sample & T-value & P-value \\
\hline Social capital----> Investment decision & 0.471 & 4.334 & 0.000 \\
Return ---------> Investment decision & 0.092 & 0.982 & 0.327 \\
Risk------------> Investment decision & 0.394 & 3.506 & 0.000 \\
Religion--------> Investment decision & -0.217 & 2.073 & 0.039 \\
\hline
\end{tabular}

The construct risk in this study was found to have a significant and positive effect $(\mathrm{T}$ statistic $=3.506>1.96)$. This means that the Minangkabau community's investment in the livestock business is also influenced by risk factors. If they feel that there is a risk in raising cows, for example an outbreak of disease or cow thefts, then they would reduce their investment. But if they feel no risk of deaths or losses of cows, then they will increase their investment. Risk is uncertainty about their investment so whether it will give them profit or loss. The results of the study are supported by Rice (2014) who argues that a risk in livestock is an investment uncertainty about investment that could bring about an advantage or a loss. Rice claims that every investor takes risks according to his investment objectives.

The risk construct in this study found significant and positive influences $(\mathrm{T}$-statistic $=3.506>1.96)$. The religious construct in this study has a rather insignificant but negative effect $(\mathrm{T}$ statistic $=2.073>1.96)$. This means that Islam as the most prevailing religion in West Sumatra, influences the Minangkabau people's investment decisions. The higher their religious belief, the lower their investment decision. Islam encourages Minangkabau farmers to practice a livestock business that promotes community welfare but forbids them to engage in financial profit of the business. This is in line with result of Islamoğlu et al. (2015) who examined the relationship of religion and investment decisions. The Return construct does not significantly influence ( $\mathrm{T}$ statistic $=0.982<1.96)$ the investment decision. This means that the Minangkabau people's investment decisions in the business of cattle are not affected by return. Big or small, the return they get from their investment in the business does not affect their investment decisions.

The results of this study are not in line with those of several studies on investment decisions. Many studies suggest that the expected rate of return is an important factor because it will guide investment choices. When people invest money in something, the main goal is to benefit from it (Suman and Warne, 2012). The findings of a study by Nagy and Obenberger (1994) which examine factors influencing investor behavior, suggest that classical wealth maximization criteria are important for investors. When people invest their money in something, the main goal is to benefit from it. They do not hesitate to invest in risky businesses because they think that high risk can give them high returns (Suman and Warne, 2012). This difference in results occurred because the Minangkabau people's investing decisions in livestock business is driven by the desire to help relatives improve their live. This is corroborated by the answers of the majority respondents who claimed that if they get a profit that is less than the investment in cows, they would not be upset or bothered. The meaning of the return is not their orientation in investing in the livestock business.

\section{Conclusion}

The Minangkabau ethnic group has contributed to the development of livestock in Indonesia, through people's cattle farm effort. Minangkabau community's investment in cattle business through the seduaan system is influenced by social capital, risk and religion. However, this study found that cattle business revenues do not affect the community's investment decisions. The Minangkabau ethnic group investment in the cattle business through the seduaan system is driven by the good faith of each community member as they look forward to long term rewards instead of pursuing quick and easy money. The study also showed that the decision to invest in the cattle business by the Minangkabau people is also driven by the desire to participate in agricultural business to help relatives who are in need. However, it is important to note that religion, on the other hand, harms the investment decisions of the Minangkabau people. This means that the higher their religious beliefs, the lower their investments. There is increasing religious pressure on the community to just view cattle business as a mutual help instead of a pure profit-oriented agricultural business investment. 


\section{Suggestions}

1. The social capital that has been built by the Minangkabau ethnic group in the effort to improve the living conditions of farmers by increasing their income through the old system seduaan needs to be maintained and preserved through socializing activities targetting the youths, academics and agricultural investors

2. The development of this investment program should be increased at the institutional level such as in cooperatives or community institutions both formal and informal

\section{Acknowledgment}

The authors are grateful to the Ministry of Research and Technology, Directorate General of Higher Education for providing funds for this research. Special thanks to the Institute of Research and Community Service (LPPM) of Andalas University which provided information related to the selection of proposals, reports and publications that helped to achieve this study.

\section{Author's Contributions}

All authors equally contributed in this work.

\section{Ethics}

This research has been approved by the Committee of Ethics of the Faculty of Agriculture of Andalas University Padang, Indonesia and therefore, no ethical issues may arise after the publication of this research.

\section{References}

Basyar, B., 2018. Livestock counseling policy formulation process at the macro level to achieve beef-self sufficiency in West Sumatera. J. Legal Ethical Regulatory.

Chin, W.W., 1998. The Partial Least Square Approach for Structural Equation Modeling. In: Methodology for Business and Management, Marcoulides, G.A. (Ed), Modern Method for Business Research, Mahwah, pp: 295-336.

Darwis, R., 2004. Transformasi Nilai-Nilai Tradisi Kekeluargaan Masyarakat Minangkabau dalam Pendidikan Kewirausahaan. 1st Edn., Pustaka Aulia Press, Bandung.

Fitrimawati, 2013. Modal sosial dan pembangunan keusahawanan kaum kerabat etnik Minangkabau melalui pertubuhan sukarela di perantauan. Prosiding.
Fitrimawati, 2015. Entrepreneurship and social capital of the Minangkabau: A comperative analysis between Minangkabau in Ranah Minang and non-Ranah Minang areas. Dissertation. National University of Malaysia, Malaysia.

Hair, J.F., 2006. Multivariate Data Analysis. 6th Edn., Pearson Educational, Inc., New Jersey.

Henri, Y., 2013. Dinamika pengembangan sapi pesisir sebagai sapi lokal Sumatera Barat. J. Penelitian Pengembangan Pertanian, 32: 39-45.

Indrayani, 2012. Analisa efisiensi teknis usaha penggemukan sapi potong di kabupatenagam provinsi sumatera barat. J. Peternakan Indonesia.

Islamoğlu, M., M. Apan and A. Ayvali, 2015. Determination of factors affecting individual investor behaviours: A study on bankers. Int. J. Econ. Financial, 5: 531-543.

Kadariya, S., 2012. Factors affecting investor decision making: A case of Nepalese capital market. J. Res. Econ. Int. Finance, 1: 16-30.

Kusnendi, 2008. Model-model persamaan struktural: Satu dan multigroup sampel dengan lisrel. Alfabeta, Bandung.

Nagy and Obenberger, 1994. Factors influencing investor behavior. Financial Anal. J., 50: 63-68. DOI: 10.2469/faj.v50.n4.63

Naim, M., 1984. Merantau pola imigrasi suku Minangkabau. Gajah Mada University Press

Rice, V.R., 2014. Risk Perception and Risk Tolerance. In: The Psychology of Financial Decisionning and Investing, Kent Baker, H. and V. Ricciardi (Eds.), Wiley, Hoboke, $\mathrm{Nj}$, pp: 327-345.

Sarwar, A. and G. Afaf, 2016. A comparison between psychological and economic factors affecting individual investor's decision-making behavior. Cogent Bus. Manage.

Suman and D.P. Warne, 2002. Investment behavior of individual investors in stock market. Int. J. Res. Finance Market., 2: 2231-5985.

Yulia, Y., L. Baga and N. Tinaprilla, 2017. Peran dan strategi pengembangan subsektor peternakan dalam pembangunan kabupaten agam sumatera barat. J. Agribusinis Indonesia. 